\title{
STRATEGI ADAPTASI KEARIFAN LOKAL MASYARAKAT NELAYAN TERHADAP PERUBAHAN EKOSISTEM PESISIR ACEH
}

\author{
ARFRIANI MAIFIZAR \\ Sosiologi Ilmu Sosial dan Ilmu Politik Universitas Teuku Umar \\ email: rian_maya@yahoo.com
}

\begin{abstract}
This study includes the importance of maintaining local wisdom by fishing communities in the face of adaptation to the impact of ecosystem changes on Sabang Island. Through deepening of the literature review, in-depth interviews, observations, and focus group discussions were conducted with local fishing communities in the coastal area of Sabang Island, finally found some research results that made reference to the adaptation strategies that fishermen community carried to the impact of ecosystem changes through local wisdom. The results show that Sabang Island fishermen communities who have felt the impact of ecosystem changes such as mangrove damage, coral reefs due to exploitation of coastal resources and natural disasters can achieve the success of solving the problem in several ways either through knowledge about adaptation made by fishing communities obtained from academic knowledge, or through knowledge that has been entrusted in a downward manner known as local wisdom. Therefore, fisherman adaptation strategies in addressing the impacts of ecosystem change follow a pattern of reactive adaptation, they tend to use capabilities from within the community. This adaptation pattern is carried out by developing job diversification, modifying the fleet of boats and taking action with the community in rehabilitating damaged ecosystems and the role of commander laot to the fishermen in arranging the time of catching with the natural sign through the knowledge of inheritance as local wisdom that needs to be maintained all the time.
\end{abstract}

Keyword: Fisherman Society, Adaptation, ecosystem change, local wisdom.

\section{PENDAHULUAN}

Masyarakat nelayan merupakan masyarakat kawasan pesisir yang memerlukan perhatian secara akademis, mengingat kehidupan pesisir tidak terlepas dari bagian sosial dalam kehidupan ini.Pulau Sabang merupakan salah satu dari sekian banyak pulau di Indonesia yang mengalami perubahan ekosistem. Perubahan ekosistem dapat disebakan oleh aktivitas masyarakatataupun bencana alam. Bencana tsunami telah 
mengakibatkan sebagian besar kawasan pesisir beserta ekosistemnya mengalami kerusakan. Menurut data Badan Rehabilitasi dan Rekonstruksi (BRR) NAD-Nias, bencana tsunami telah menyebabkan kerusakan mangrove seluas 174.590 ha, terumbu karang 19.000 ha, dan hutan pantai 50.000 ha. Sementara itu, laporan Wetlands Internasional Indonesia Programme (WIIP) menyatakan, akibat dari bencana Tsunami, lahan-lahan basah di Provinsi Aceh (terutama yang terletak di pantai utara, barat laut dan barat daya Aceh) diduga telah banyak mengalami perubahan bentuk, luasan, maupun kualitas air dan substrat dasarnya.

Secara sosio-kultural masyarakat pesisir merupakan suatu kelompok masyarakat yang akal budayanya pada mulanya dibangun atas panduan antara budaya maritime laut, pantai dan berorientasi pantai. Perbedaan mendasar masyarakat pesisir dan masyarakat agraris adalah pada akses terhadap sumberdaya. Sangat berbeda dengan sumberdaya lahan pada masyarakat agraris, laut merupakan sumber daya alam open acces sehingga siapapun dapat mengaksesnya. Sumber daya yang bersifat terbuka ini menyebabkan persaingan antar nelayan menjadi semakin keras. Tidak mengherankan jika nelayan atau penduduk pesisir pada umumnya memiliki karakter yang keras. Terlebih risiko pekerjaan yang tinggi baik dalam keselamatan jiwa maupun ekonomi

Keberadaan ekosistem pesisir memiliki fungsi dan peranan penting pada pulau kecil. Menurut Bengen (2012) fungsi dan peranan ekosistem pulau-pulau kecil sebagai pengatur iklim global, siklus hidrologi dan biogeokimia, penyerap limbah, sumber plasma nutfah dan sistem penunjang kehidupan lainnya. Supriharyono (2007) menyebutkan sejumlah organisme bernilai ekonomi yang kehidupannya bergantung pada ekosistem karang, yaitu penyu, udang barong, octopus, conches, kerang, oyster, rumput laut, kima dan teripang. Ketika salah satu ekosistem berubah maka akan mempengaruhi ekosistem lain di sekelilingnya, termasuk manusia yang mengantungkan kehidupan pada ekositem pesisir.

Masyarakat yang berada di kawasan pesisir juga menghadapi berbagai pemasalahan. Febrianto \& Rahardjo, (2005) menjelaskan pada umumnya masyarakat menggantungkan hidupnya dari pemanfaatan sumber daya laut dan pantai yang membutuhkan investasi besar dan sangat bergantung musim. Sebagian besar dari mereka bekerja sebagai nelayan kecil hanya mampu memanfaatkan sumberdaya di daerah pesisir dengan hasil tangkapan yang cenderung terus menurun akibat persaingan dengan kapal besar dan penurunan mutu sumber daya pantai. Hasil tangkapan juga mudah rusak karena ekosistemnya banyak yang hancur.

Perubahan ekosistem di Pulau Sabang ditandai dengan kerusakan ekosistem mangrove dan terumbu karang. Kerusakan yang terjadi pada ekosistem terumbu karang pada akhirnya memengaruhi populasi ikan dan dapat berimplikasi pada aktivitas melaut dan perekonomian para nelayan (Satria, 2009).

Semakin tinggi tingkat adaptasi, maka semakin besar kemampuannya untuk mempertahankan kehidupannya dan mempengaruhi kelangsungan hidup makhluk 
Community: Volume 4, Nomor 1, April 2018

ISSN: $2477-5746$

lainnya (Rapaport 1999). Namun demikian, adanya perbedaan morfologi suatu wilayah mempengaruhi perbedaan respon manusia (Gilman dkk. 2007). Berdasarkan hasil pemaparan kondisi adanya perubahan ekosistem di kawasan pesisir Pulau Sabang. Penelitian ini dimaksudkan untuk melihat strategi adaptasi yang dilakukan masyarakat Pulau Sabang dalam menghadapi dampak perubahan ekosistem.

\section{Masalah penelitian}

Berdasarkan latar belakang permasalahan mengenai kearifan lokal dan adaptasi yang di lakukan masyarakat nelayan di wilayah pesisir pulau sabang, maka dirumuskan masalah penelitian sebagai berikut:

1. Bagaimana strategi adaptasi masyarakat nelayan dalam menghadapi dampak perubahan ekosistem pesisir pulau sabang?

2. Bagaimana kearifan lokal yang pergunakan oleh masyarakat nelayan dalam melakukan adaptasi terhadap perubahan ekosistem?

\section{Tujuan Penelitian}

Berkaitan dengan masalah yang telah dikemukakan di atas, maka secara umum penelitian ini bertujuan menemukan strategi strategi adaptasi masyarakat nelayan dalam menghadapi dampak perubahan ekosistem pesisir pulau sabang dan mengetahui kearifan lokal yang telah dipergunakan oleh masyarakat nelayan dalam melakukan adaptasi terhadap perubahan ekosistem pesisir pulau sabang.

\section{Manfaat Penelitian}

Berdasarkan tujuan penelitian yang ingin dicapai, hasil-hasil penelitian ini diharapkan mampu memberikan manfaat bagi semua pihak yang terkait, yakni:

1. Secara akademis diharapkan penelitian ini dapat pengetahuan baru mengenai strategi dan cara adaptasi masyarakat nelayan dalam menghadapi dampak perubahan ekosistem pesisir

2. Secara praktis diharapkan memberikan sumbangan atau masukan bagi pemerintah Diharapkan dengan dapat menjadikan rujukan bagi akademisi, tokoh adat, pemerintah daerah serta instansi yang terkait. Sehingga dapat pemecahan masalah kawasan pesiisr.

\section{TINJAUAN PUSTAKA}

Djunaidi (2007) mengatakan bahwa pada umumnya masyarakat pesisir telah menjadi bagian masyarakat yang pluralistik, tetapi masih memiliki jiwa kebersmaan. Masyarakat pesisir mempunyai sifat-sifat atau karakteristik tertentu yang khas/unik. 
Sifat ini sangat erat hubugannya dengan sifat usaha dibidang perikanan sangat dipengaruhi oleh factor-faktor lingkungan, musim dan pasar.

Menurut Putra (2014) bahwa pola migrasi ikan terjadi karena kerusakan terumbu karang akibat proses upwelling, sehingga hal ini memicu ikan bermigrasi mencari tempat yang memiliki terumbu karang yang lebih baik. Selain itu, perubahan ekosistem berdampak pada aktivitas sosial ekonomi masyarakat yang meliputi perubahan waktu melaut, daerah tangkapan ikan dan jumlah tangkapan ikan (Saguna, 2016). Terjadinya perubahan ekosistem di kawasan pesisir Pulau Sabang menyebabkan masyarakat nelayan hidup dalam suatu lingkungan yang tidak menentu. Menurut Kusnadi dkk (2007) bahwa kondisi masyarakat nelayan atau masyarakat pesisir diberbagai kawasan secara umum ditandai dengan adanya kemiskinan, keterbelakangan sosial-budaya rendahnya kualitas sumberdaya manusia (SDM) serta kapasitas berorganisasi masyarakatnya.

Dampak perubahan tersebut telah menambah kerentanan terhadap wilayah, dengan munculnya kepanikan nelayan terhadap hasil tangkap, dan menurunnya populasi ikan yang berdampak pada penghasilan nelayan. Bukan hanya di Pulau Sabang, saat ini permasalahan kerentanan masyarakat pesisir akibat perubahan ekosistem bukanlah hal baru yang dihadapi oleh masyarakat. Untuk mengurangi dampak buruk, beragam upaya telah dilakukan perlu sejak dini komunitas nelayan. Salah satu upayanya adalah dengan melakukan upaya adaptasi terhadap perubahan lingkungan fisik maupun sosial yang terjadi secara temporal. Sampai saat ini pemerintah terkait melalukan upaya penyuluhan terkait langkah adaptasi yang seharusnya dilakukan para nelayan. Adaptasi merupakan suatu sistem interaksi yang berlangsung terus antara manusia dengan manusia, dan antara manusia dengan ekosistemnya (Helmi dan Satria, 2012).

\section{METODE PENELITIAN}

Penelitian ini menggunakan metode kualitatif. Metode kualitatif ini digunakan untuk mengetahui adaptasi yang dilakukan nelayan dalam menghadapi perubahan ekosistem. Pendekatan yang digunakan dalam penelitian ini adalah deskriptif. Penelitian deskriptif berguna untuk membuat penjelasan secara sistematis, faktual, dan akurat mengenai fakta-fakta dan sifat-sifat populasi atau daerah tertentu. Penelitian ini dilakukan di Pulau kota Sabang. Pemilihan lokasi tersebut dilakukan secara sengaja (purposive). Data yang dikumpulkan meliputi data primer dan data sekunder. Data primer yang diperoleh dari responden dilakukan melalui teknik wawancara dengan alat bantu panduan wawancara yang telah dipersiapkan. Selain data primer, pengumpulan data dalam penelitian ini juga menggunakan data sekunder. Sumber data sekunder dapat diperoleh dari Kantor Desa, BPS, Dinas Perikanan dan Kelautan Sabang, serta laporan penelitian yang ada kaitannya dengan penelitian ini. Teknik analisis data dilakukan sejak awal pengumpulan data. Hasil wawancara mendalam dan pengamatan disajikan dalam bentuk catatan harian yang dianalisis sejak pertama 
Community: Volume 4, Nomor 1, April 2018

ISSN: $2477-5746$

kali datang ke lapangan dan berlangsung terus menerus yang terdiri dari pengumpulan data, analisis data, reduksi data, penyajian data, dan penarikan kesimpulan.

\section{TEMUAN DAN PEMBAHASAN}

\section{Kondisi Geografis Pulau Sabang}

Berdasarkan laporan Sabang dalam Angka (2016) diketahui yaitu secara geografis Kota Sabang terletak pada koordinat antara 95 $13^{\prime} 02^{\prime \prime}$ hingga $95^{\circ} 22^{\prime} 36^{\prime \prime}$ BT dan antara $05^{\circ} 46^{\prime} 28^{\prime \prime}$ hingga $05^{\circ} 54^{\prime} 28^{\prime \prime}$ LU dengan ketinggian rata-rata 28 meter diatas permukaan laut. Secara adminstratif Kota Sabang berbatasan dengan Selat Malaka yaitu sebelah utara dan timur, sebelah selatan dan barat berbatasan dengan Laut Andaman. Sabang terbagi menjadi dua kecamatan, yaitu Kecamatan Sukajaya dan Kecamatan Sukakarya, serta terbagi menjadi 18 Gampong (desa). Kota Sabang terdiri dari 5 pulau, yaitu Pulau Weh, Pulau Klah, Pulau Rubiah, Pulau Seulako dan Pulau Rondo ditambah gugusan pulau-pulau batu di Pantee Utara.

Pulau Sabang merupakan pulau terluas dan merupakan satu-satunya pulau yang dijadikan pemukiman, sedangkan Pulau Rondo merupakan salah satu pulau terluar yang berjarak $\pm 15,6 \mathrm{~km}$ dari Pulau Weh. Luas keseluruhan Kota Sabang ialah 933,39 km2, dengan luas daratan 122,14 km2 dan luas perairan 811,26 km2 (BAPPEDA Kota Sabang 2016).

Pulau Sabang memiliki dua musim yang terbagi menjadi musim barat dan musim timur dimana kondisi iklim di derah ini relatif samadengan daerah-daerah lainnya di Indonesia. Musim barat terjadi pada Bulan November hingga Januari dimana angin bergerak dari arah barat ke arah timur dan memiliki suhu yang relatif rendah $\left(26^{\circ} \mathrm{C}\right)$ dan curah hujan yang paling tinggi $(353,8 \mathrm{~mm})$. Musim timur terjadi pada Bulan Mei hingga Juli dengan arah bergeraknya angin berasal dari arah Timur ke arah Barat dan Barat Daya. Rata-rata suhu udara saat musim timur dapat mencapai $28,40^{\circ} \mathrm{C}$.

\section{Adaptasi Terhadap Perubahan Ekositem Pulau Sabang}

Perubahan ekosistem yang terjadi di Pulau Sabang diakibatkan karena faktor bencana alam Tsunami dan aktivitas masyarakat dalam memanfaatkan ekosistem. Perubahan ekosistem berpengaruh pada produktivitas perikanan juga disebabkan oleh rusaknya ekosistem hutan bakau dan terumbu karang akibat meningkatnya suhu permukaan air laut dan perubahan air tanah (Nurlaili, 2012). Sejumlah permasalahan perubahan ekosistem telah berdampak pada usaha dan profesi masyarakat nelayan sebagai pencari ikan san sebagaimana telah dipaparkan sebelumnya. Dampak yang dirasakan bukan hanya oleh nelayan, namun seluruh masyarakat di Pulau Sabang. 
Salah satunya perubahan ekosistem telah menyebabkan menurunnya hasil tangkapan nelayan, sehingga harga ikan menlonjak mahal. Menurunnya hasil tangkapan mempengaruhi penghasilan nelayan. Kondisi tersebut menyebabkan sebagian masyarakat mulai sadar bahwa kehidupan mereka makin tidak aman jika terus bertahan dengan kondisi demikian. Menyadari hal tersebut masyarakat nelayan Pulau Sabang tidaklah pasrah, melainkan melakukan sejumlah langkah sebagai strategi dalam mengantisipasi keadaan tersebut. Salah satu langkah yang dilakukan adalah strategi adaptasi menyesuaikan diri dengan perubahan. adaptasi yang dilakukan merupakan tindakan usaha dalam mengurangi kerentanan yang terjadi. Adapun adaptasi yang di lakukan oleh masyarakat nelayan adalah adaptasi reaktif. Strategi Adaptasi ini dilakukan setelah dampak perubahan ekositem terjadi semakin parah dan terpuruk keadaannya. Beberapa strategi adaptasi reaktif yang dilakukan oleh nelayan yaitu sebagai berikut:

\section{Mengembangkan Diversifikasi Pekerjaan}

Ketika tidak melaut karena ikan tangkapan semakin sedikit. Nelayan melakukan pengembangan mata pencaharian pada sektor lainya. Pengembangan ragam mata pencaharian guna memenuhi kebutuhan ekonomi rumah tangga dilakukan oleh komunitas nelayan. Hal itu dilakukan ketika kondisi alam tidak memungkinakan untuk melaut. Aktivitas yang dilakukan diluar kegiatan penangkapan ikan merupakan salah satu adaptasi yang dilakukan dalam menghadapi fluktuasi musim ikan dan cuaca yang tidak menentu (Allison et al. 2001). Aktivitas di luar kegiatan penangkapan ikan merupakan jalan alternatif untuk para nelayan untuk menutupi kebutuhan hidup sehari-harinya dengan memiliki pekerjaan sampingan (Haryono, 2005). Sektor perikanan di Pulau Sabang sangat rentan terhadap perubahan ekosistem. Sedangkan komunitas nelayan di Pulau Sabang umumnya adalah nelayan tradisional yang sangat bergantung kondisi laut dan perikanan. Ketika terjadi krisis ikan dampak dari perubahan ekosistem sebagian besar nelayan memilih mengembangkan ragam pencaharian di sektor non perikanan.

Guna memenuhi kebutuhan rumahtangga pengembangan ragam mata pencaharian dilakukan dengan berjualan ditepi pantai, menjadi petugas penjaga tempat penginapan dan bagi nelayan yang memiliki boat. Pada saat tidak melaut Boat di sewakan untuk membawa wisatawan mengelilingi pulau rondo dan pulau rumbiah.Pealihan profesi dikarenakan keadaan cuaca ini selain meningkatkan pendapatan nelayan juga memasukan devisa bagi negara khususnya pemerintah daerah. Bagi nelayan yang tidak memiliki boat, upaya strategi adaptasi dilakukan dengan berjualan di tepi pantai. Keramaian pengunjung pantai merupakan kearifan alam yang terbentang untuk dijadikan pusat perdagangan. Dagangan yang di jajakan ditepi pantai umumnya adalah makanan ringan, mie aceh, dan kelapa muda. Menurut mereka langkah berjualan kelapa muda lebih menguntungkan karena tidak perlu mengeluarkan modal banyak. Hal itu dikarenakan kondisi geografi rumah masyarakat 
Pulau Sabang memiliki lahan luas yang hampir setiap rumah memiliki pohon kelapa.Kekayaan alam merupakan salah satu stategi yang dapat di pergunakan dengan sangat bijak demi keberlangsungan kehidupan khususnya pemasukan pendapatan masayarakat nelayan di pulau sabang.

Saat tidak melaut, masyarakat nelayan yang tidak memiliki lapak berjualan memilih bekerja sebagai petugas kebersihan dan keamanan di kawasan penginapan.Strategi ini juga merupakan pilihan profesi yang tepat dalam mempertahankan perubahan situasi yang terjadi. Pilihan menjadi petugas keamanan di anggab lebih mudah dan dapat dilakukan dengan sistem shift. Mereka yang bekerja sebagai pengawas keamanan di tempat penginapan mendapatkan penghasilan antara Rp. 40 ribu sampai bahkan diatas Rp. 80 ribu perhari. Kalau akhir tahun, ada event atau pameran bisa mendapatkan 300 ribu perhari. Sedangkan nelayan yang hanya bekerja sebagai nelayan saja belum tentu mendapatkan penghasilan sebesar itu. Sebagaimana diungkapkan pula oleh salah seorang nelayan, MHD (52 tahun) pada bulan Juni 2017 :

Ketika tidak melaut, tidak ada pilihan lain bang. Hidup harus diperjuangkan. Kita lakukan apa yang bisa kita lakukan. Disela sela tidak melaut kita berjualan saja asalkan halal. kerena orang dipulau ini jarang merantau. Paling pindah cari pekerjaan hanya diseputaran Pulau, jarang sekali menyebrang. Kalau nyebrangpun mahal di ongkos. Belum tentu juga nanti dapat pekerjaan.

Mengembangkan diversitas pekerjaan merupakan cara nelayan di pulau Sabang beradaptasi dengan perubahan ekosistem. Hal ini dikarenakan umumnya masyarakat Pulau sangat rendah mobilisasi. Rendahnya mobilitas ini disebabkan rendahnya ketersediaan sarana dan prasarana transportasi laut, dan rendahnya frekuensi jasa transportasi yang menghubungkan antar kawasan kepulauan, sehingga biaya transportasi menjadi sangat mahal. Tidak ada pilihan lain selain bertahan dengan kondisi perubahan, dan menggunakan kemampuan dari dalam diri komunitas untuk menyesuaikan dengan perubahan yang terjadi. Ketika kondisi laut membaik mereka segera meninggalkan kerja sampingan tersebut untuk melaut kembali.

\section{Memodifikasi Armada Perahu}

Penyesuian yang dilakukan nelayan menghadapi perubahan ekosistem adalah dengan memodifikasi armada perahu. Menurut Imron (2003) modernitas alat tangkap akan mempengaruhi kemampuan jelajah operasional nelayan. Kondisi nelayan di Pulau Sabang. Nelayan yang memiliki perahu bermesin, melakukan penyesuaian dengan merubah fungsi perahu dari menangkap ikan, menjadi fungsi mengantarkan wisatawan. Ketika musim paceklik tiba, nelayan yang memiliki perahu menggunakan perahu mereka sebagai jasa pengangkutan wisatawan. Perahu di modifikasi dan di hias sedemikian rupa untuk kemudian di sewa sebagai sarana pengangkut wisatawan yang hendak berkunjung ke Pulau rondo ataupun pulau Rubiah. Aktivitas antar 
jemput wisatawan sering disebut dengan tarik sewa. Tarik sewa perahu menjadi profesi yang menggiurkan bagi sebagian nelayan yang memiliki perahu. Karena patokan harga sewa perahu untuk untuk sekali mengatar wisatawan mengililingi pulau rubiah patokan harga antara 150-300 per 4 jam. Ada juga yang menawarkan paket komplit 500 ribu/perhari. Namun tidak semua yang memodifikasi perahu berhasil memperoleh keuntungan dengan merubah perahu. Tidak sedikit juga yang mengeluh karena ketiadaan penyewa. Sebagaimana diungkapkan pula oleh salah seorang nelayan, MM (48 tahun) pada bulan Juni 2017 :

"Dibulan bulan seperti ini yang sedikit wisatawan. Kita nelayan kecil kalah saing dengan penyedia jasa travel. Sekarang itu orang kesabang banyak yang pake jasa travel dan online. Dari tempat tidur, tempat makan, mobil dan perahu sudah disediakan. Kalau orang bulek jarang sekali mau menyewa. mereka lebih pilih jasa tranvel, karena pengemudi perahu bisa berbahasa inggris"

Kondisi nelayan yang melakukan tarik sewa perahu kini memprihatikan karena mulai kurang penyewa. Maraknya bisnis online jasa wisata yang menawarakan jasa penjemputan, penginapan, sampai penyewaan perahu untuk mengantaran kepulau rumbia. Selain itu wisatawan manca negara biasanya lebih memilih perahu yang dikemudikan oleh nelayan yang mampu berbahasa inggris. Sedangkan nelayan pada umumnya sangat minim penguasaan bahasa asing.Keterbatasan tersebut menyebabkan aktivitas tarik sewa minim penyewa. Tarik sewa hanya mengandalkan wisatawan lokal biasa, dan biasanya hanya banyak pada waktu tertentu, seperti tahun baru dan menjelang masuk bulan ramadhan. Fenomena sosial di atas menjadikan masyarakat nelayan di pulau sabang harus memiliki skill dalam berbahasa asing sehingga mampu bersaing dengan nelayan-nelayan yang datang dari luar pulau dan menetap di pulau sabang.

Dalam tradisi masyarakat kepulauan, ada aktivitas rekreasi pantai yang dilakukan oleh masyarakat nelayan, menjelang masuknya bulan ramadhan. Aktivitas ini sering disebut dengan "rabuu abeh". Nelayan yang mengandalkan wisatawan lokal mampu bertahan karena membangun jaringan sosial dengan langganan. Langganan yang menaruh kepercayaan biasanya akan menelpon untuk memesan perahu pada nelayan tersebut. Sebaliknya nelayan menaruh harapan pada langganan untuk terus menjadikan armada miliknya selalu disewakan langganan. Masyarakat nelayan di Pulau Sabang memiliki solidaritas sesamanya. Hal ini terlihat dari aksi kerjasama saling membantu. Nelayan yang tidak memiliki perahu, mereka memilih untuk ikut melaut bersama kelompok nelayan. Melaut bersama merupakan alternatif untuk mencari pendapatan ketika terjadi angin dan gelombang sangat kencang. Budaya "Rabu Abeeh" menjadikan masyarakat nelayan terjalin secara dinamis dalam ikatan persaudaraan dan interaksi sosial yang kuat dia antara sesamanya.Budaya adat ini menjadi arena tempat berkumpulnya dan wadah kegiatan sosial yang dilakukan oleh seluruh masyarakat nelayan. 
Community: Volume 4, Nomor 1, April 2018

ISSN: $2477-5746$

\section{Mengatur Waktu Penangkapan dengan tanda alam dan bulan}

Pada masyarakat Pulau Sabang terdapat pedoman budaya melaut dari nenek moyang untuk menentukan kapan harus melaut. Budaya terbentuk lebih dominan karena proses pengalaman, yang di sosialisasikan turun temurun. Pada komunitas nelayan di Pulau Sabang terdapat nilai budaya dan aturan yang berkaitan dengan waktu penangkapan. Budaya dan aturan yang berkaitan dengan waktu penangkapan tersebut memberi pengetahuan, arahan dan pedoman untuk menyesuaikan diri dengan perubahan yang terjadi. Perubahan ekosistem telah menyebabkan sulitnya nelayan memperoleh hasil tangkapan di suatu wilayah ditambah semakin berkurangnya keragaman ikan karang di Pulau Sabang. Dalam pengetahuan yang berkembang dalam komunitas nelayan. Ada pemahaman terkait dengan waktu dimana ikan dan jenis biota laut lainnya pada kondisi tertentu sangat melimpah,dan melintas di laut. Pengalaman kondisi tersebut memberi pengetahuan akan waktu dan kondisi alam.

Belajar dari kondisi tersebut kemudian menghasilkan bentuk adaptasi terhadap perubahan dengan mengatur waktu penangkapan. Mengatur waktu penangkapan dilakukan dengan pengetahuan membaca tanda Alam dan menghitung rumus "jatuh bulan" dalam bahasa komunitas nelayan disebut dengan "Buleun Keuneunong" artinya bulan kena. Berpedoman pada tanda alam dan tanda bulan, sebagian besar nelayan yang mengerti akan melakukan pengaturan waktu penangkapan pada waktu tersebut, dan tidak melaut di luar waktu tersebut. Dalam Fokus Group Diskusi yang dilakukan bersama masyarakat nelayan, ditemukan beberapa tanda alam dan cara menghitung "keuneunong" yang digunakan oleh nelayan untuk menyesuaikan dengan perubahan yang terjadi.

Berikut adalah tanda alam yang berkembang dan digunakan nelayan untuk mengatur waktu penangkapan yang terbagi dalam beberapa tahapan di bawah ini,diantaranya :

Tanda pertama, keadaan langit bersisik. Menurut nelayan senior ikan akan naik ke permukaan pada saat langit bersisik. Langit bersisik yang dipenuhi awan bergaris, biasanya para nelayan akan pergi kelaut untuk menangkap ikan dan hampir pasti selalu mendapatkan hasil tangkapan yang melimpah ruah.

Tanda kedua, melihat alur arus (Alur arus kebarat). Dalam pengetahuan yang berkembang di komunitas nelayan musim ikan dapat ditentukan berdasarkan arah arus mengalir. Menurut nelayan kalau arus air laut kearah barat maka suhu air laut menjadi panas (hangat) sehingga ikan muncul kepermukaan dan sangat mudah untuk ditangkap. Namun jika arah arus mengarah ketimur maka air laut akan menjadi sangat dingin dan ikan-ikan masuk kedasar laut sehingga pada masa itu merupakan masa paceklik bagi para nelayan. Tanda alam ketiga, melihat masa peneduh diantara musim barat dan musim timur. Masa ini menurut nelayan lobster akan muncul dari permukaan karang, jenis ikan karang 
dan ragam ikan lainnya banyak ditemukan. Masa peneduh planton berkumpul pada titik dekat dengan karang akibat perubahan musim. Titik berkumpul planton biasanya titik berkumpulnya banyak jenis ikan. Pada kondisi ini biasanya nelayan berlomba lomba menangkap ikan.

Tanda alam keempat, melihat daun-daun di pohon sudah mulai rontok. Jika daun-daun pada pepohonan keras sudah mulai berjatuhan (musim gugur daun). Maka menurut pengetahuan yang berkembang pada masyarakat nelayan, kondisi tersebut merupakan salah satu pertanda bahwa musim ikan seperti tongkol, ame-ame dan cakalang sudah mulai melimpah. Artinya petunjuk rontoknya daun-daun merupakan salah satu pertanda datangnya musim ikan tertentu. Dalam mengatur waktu penangkapan ikan. Pada komunitas nelayan dikenal dengan sistem ramalan bintang berdasarkan perhitungan tanggal. Istilah dalam masyarakat Aceh disebut "Keuneunong" (kena). Keuneunong merupakan waktu yang dipercaya pertemuan tanda kala dan bulan di langit. Dalam kepercayaan komunitas nelayan waktu tersebut dapat prediksi dan dihitung.

Dengan menggunakan pengaturan waktu tersebut pada waktu tertentu terjadi dapat diprediksi kelimpahan ikan, melintasnya lumba lumba, keberadaan hiu, pulangnya penyu untuk bertelur ke Pulau Sabang dan lainnya. Menentukan waktu yang terbaik melaut dapat ditentukan dengan rumus keunong yaitu rumus 25 - jumlah bulan bulan ke [.......] di kali 2 misalnya Bulan November adalah bulan ke 11, jadi 25 $(11 \times 2)=3$ maka November masuk pada keuneunong 3, angka 25 didapatkan dari jumlah bulan dalam 1 tahun di kali 2 di tambah 1 sehingga $12 \times 2+1=25$. Namun alasan perhitungan tersebut tetap menjadi misteri yang belum terpecahkan. Jika dihitung dengan rumus diatas didapatkan masing-masing bulan dengan jatuh "keuneunong". Sebagaimana diungkapkan pula oleh pawang laot, MM (56 tahun) pada bulan Juni 2017 :

Sebenarnya dalam dunia pelayaran tradisional komunitas nelayan disini masih menggunakan banyak petunjuk alam, bukan hanya petunjuk alam dan bulan. Ada banyak petujuk yang di ketahui oleh nelayan disini. Termasuk petunjuk akan datangnya Tsunami. Petunjuk cara mengenali rasi bintang dilangit yang digunakan sebagai patokan dalam palayaran. Pokoknya banyak, kita upayakan petunjuk ini terus di pelihara dijaga dengan baik.

Adaptasi dengan mengatur waktu penangkapan melalui tanda alam dan tanda bulan menjadi perhatian utama berkaitan dengan aktivitas subsisten dan pengaturan ekonomi. Sistem pengetahuan yang dikembangkan oleh masyarakat nelayan ini merupakan salah satu strategi yang sangat ampuh yang telah teruji dapat mengatasi kerentanan yang hadir akibat perubahan ekosistem. Dalam komunitas nelayan punya filosofis berkaitan dengan strategi melaut yaitu "hudep di laot hanjet tarubah angen, tapi jeut tarubah layeuu untuk tamita razeki" (Hidup di laut memang tidak bisa merubah arah angin, namun kita bisa mengubah layar untuk mencari rezeki). Pengetahuan dan 
kemampuan membaca tanda alam dan bulan yang dimiliki oleh komunitas nelayan di Pulau Sabang telah memberikan ruang bagi masyarakat untuk beradaptasi terhadap perubahan ekositem.

Komunitas nelayan mampu bertindak dan berpikir dengan cara membaca kondisi alam tertentu karena telah disosialisasikan dalam budaya yang mereka terima. Sehingga pembahasan mengenai dampak dari perubahan ekosistem sebenarnya bukan sekedar berkaitan dengan adaptasi dan budaya nafkah. Namun jauh dari itu perubahan ekosistem telah menyebabkan penyesuaian dalam pengaturan penghidupan komunitas nelayan di Pulau Sabang. Hal ini senada dengan Bengen (2012), masyarakat di pulau-pulau kecil memiliki karakteristik sosial budaya tersendiri, sebagai konsekuensi dari proses evolusi budaya yang terjadi dalam suatu rangkaian proses interaksi manusia dan lingkungannya. Masyarakat nelayan umumnya telah memiliki pengetahuan tentang strategi penyesuaian yang harus di lakukan terkait dengan dampak perubahan ekosistem. Namun beberapa pengetahuan lokal tersebut tidak selalu tepat dengan kondisi saat ini yang sangat tidak menentu dan merupakan anomali dari kondisi perubahan ekosistem yang biasa dihadapi.

Selain itu kondisi saat ini, memiliki pengetahuan saja tidak cukup, nelayan perlu skiil khusus. Hal ini juga disampaikan Subair dkk (2014) menyatakan bahwa seorang nelayan tidak cukup hanya memiliki pengetahuan dan keterampilan, mereka juga harus memiliki kekuatan dan ketahanan fisik yang besar dan prima, sehingga saat bekerja nelayan mampu melaut dengan jarak yang jauh sesuai lokasi ikan yang ditunjukkan oleh teknologi penangkapan ikan.

Secara perspektif sosiologi kiranya masyarakat nelayan mampu menyatukan pengetahuan dalam melihat alam yang telah dimiliki secara turun menurun, juga perlu di barengi dengan kemampuan pengetahuan dalam melihat alam secara akademis.strategi kolaborasi atas peran panglima laot sebagai pemuka atas pengetahuannya secara alamiah mengenai sistem alam laut dengan pakar keilmuan perikanan dan sistem lautnya menjadi patokan dalam tolak ukur untuk menegtahui secara detail permasalahan dan solusi terbaik dalam memecahkan perubahan alam,cuaca dan perubahan alam khususnya dalam melakukan penyelesaian persoalan perubahan adaptasi masyarakat nelayan terhadap ekosistem pesisir laut Aceh.

\section{Melakukan Aksi Bersama Rehabilitasi Ekosistem}

Meski banyak diantara masyarakat tidak memahami perubahan ekosistem, mereka yang penghidupannya dari hasil perikanan dan bergantung pada sumber daya alam (ikan) merasakan dampaknya. Kondisi ekosistem pesisir Pulau Sabang semakin memprihatinkan dari hari ke hari. Hal ini menjadikan pengalaman dan pemahaman yang berharga bagi masyarakat. Dampak perubahan membuat komunitas nelayan dengan sendirinya belajar dari ketidakpastian mata pencaharian dan pendapatan. Ketidakpastian mata pencaharian telah menggerakan sebagian dari anggota komunitas nelayan untuk melakukan aksi bersama merehabilitasi dan mengembalikan kondisi 
ekositem seperti sediakala. Rehabilitasi ekosistem di lakukan menanam kembali mangrove dan terumbu karang yang rusak. Penanaman kembali mangrove dan terumbu karang merupakan tindakan pro-aktif, terencana dan mengarah pada perbaikan ekosistem yang telah rusak. Awalnya penanaman mangrove hanya dilakukan sebanyak 500 batang oleh nelayan. Namun setahun terahir komunitas nelayan bekerjasama dengan anggota Marinir Basarnas, klub selam Aceh Diving Club, dan Hore Hore Dive Club (H2DC) Aceh yang turut membantu menanam kembali terumbu karang di bawah laut dermaga Pantai Gapang, hingga Iboh. Salah satu cara yang dilakukan komuitas nelayan dalam rangka merehabilitasi ekosistam adalah dengan membangun keterhubungan dengan komunitas dan antar komunitas lainya. Dengan cara menjemput kepedulian orang diluar komunitas untuk membantu dan bekerjasama merehabilitasi ekositem turumbu karang dan mangrove yang telah rusak. Aksi bersama yang dijalankan komunitas nelayan dan masyarakat luar yang peduli terhadap kerusakan ekosistem tidak lepas dari keberadaan Panglima Laot dalam komunitas nelayan.

Peran Panglima laot sebagai penghubung komunitas nelayan dan pemerintah menjadi penting dalam menggalang aksi bersama. Meskipun demikian langkah kedepan agar mangrove tidak rusak. Komunitas nelayan mengembangkan mekanisme adat dalam pengelolaan sumberdaya. Mekanisme denda adat tersebut berkolaborasi dengan sistem sanksi Panglima Laot. Selain aksi bersama merehabilitasi ekosistem. Aksi bersama yang masih kental dalam komunitas masih di lakukan nelayan seperti membatu saudara se-kawom (persaudaraan sedarah), melakukan samadiah ( mengunjungi dan membaca doa pada orang meninggal selama 7 malam) dan mengadakan kenduri laot ( acara tahunan, sebagai wujud syukur terhadap tuhan dan Alam).

\section{KESIMPULAN}

Adapun hasil kesimpulan dalam penelitian ini , diantaranya sebagai berikut :

1. Strategi terhadap perubahan ekositem akibat kerusakan mangrove dan terumbu karang karena pemanfaatan sumberdaya pesisir yang cenderung eksploitatif maupun akibat bencana tsunami, maka adaptasi yang dilakukan komunitas nelayan mengatasi dampak perubahan ekosistem menganut pola adaptasi reaktif dan menggunakan kearifan lokal yang selama ini telah di lakukan secara turun menurun.

2. Adaptasi yang dilakukan komunitas nelayan kecendrungan menggunakan kemampuan dari dalam diri komunitas. Adaptasi dilakukan dengan mengembangkan diversifikasi pekerjaan, memodifikasi armada perahu, mengatur waktu Penangkapan dengan tanda alam, dan melakukan aksi bersama rehabilitasi ekosistem.Perlibatan Panglima Laot dan Gerakan bersama elemen masyarakat dalam penangulangan masalah ini menjadi modal sosial 
Community: Volume 4, Nomor 1, April 2018

ISSN: 2477-5746

untuk kebaikan bersama khususnya mempertahankan warisan terdahulu dari wilayah pesisir laut, termasuk kekayaan isi alamnya dan masyarakat komunitas nelayan yang menjaga kelestariannya.

\section{DAFTAR PUSTAKA}

\section{Buku}

Allison EH, Ellis F. 2001. The livelihoods approach and management of small-scale fishers. Marine policy, 25, 377-388.

Bengen DG. 2012. Menguak Realitas dan Urgensi Pengelolaan Berbasis Eko-Sosio Sistem Pulau-pulau Kecil [ID]: Jakarta Pusat Pembelajaran dan Pengembangan Pesisir dan Laut (P4L)

Gilman, E., J. Ellison and R. Coleman. 2007. Assessment of mangrove response to projected relative sea-level rise and recent historical reconstruction of shoreline position. Environmental Monitoring Assessment, 124:105-130.

Haryono, T. J. S. 2005. "Strategi Kelangsungan Hidup Nelayan: Studi tentang diversifikasi pekerjaan keluarga nelayan sebagai salah satu strategi dalam mempertahankan kelangsungan hidup". Berkala Ilmiah Kependudukan, 7 (2), hal 126-127.

Imron, M. 2003. Pemberdayaan Masyarakat Nelayan. Media Pressindo: Yogyakarta.

Rappaport, R. A. 1999. Ritual and Religion in The Making of Humanity. Cambridge university Press.

Saguna aisyah, 2015. Strategi adaptasi nelayan dan faktor faktor Pelayaran dalam menghadapi Perubahan iklim, Institut Teknologi Sepuluh Nopember Surabaya. Surabaya

Satria, A. 2009. Pesisir dan Laut Untuk Rakyat. Bogor: IPB Press.

Subair, Kolopaking, L. M., Adiwibowo, S. dan Pranowo, M. B. 2014. "Resiliensi Komunitas Dalam Merespon Perubahan

Supriharyono. 2007. Pengenalan Ekosistem Terumbu Karang. Jakarta: Djambatan.

\section{Jurnal Penelitian/Skripsi/Tesis}

Helmi, A. dan Satria, A. 2012. "Strategi Adaptasi Nelayan Terhadap Perubahan

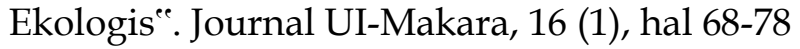


Dini Purbani, Terry Louise Kepel, 2014. Coral Reef Condition in Weh Island After Mega Tsunami Disaste. J. MANUSIA DAN LINGKUNGAN, Vol. 21, No.3: 331340

Iklim Melalui Strategi Nafkah (Studi Kasus Desa Nelayan Di Pulau Ambon Maluku)". Jurnal Sosek, 9 (1), hal 77-90.

Nurlaili. 2012. "Strategi Adaptasi Nelayan Bajo Menghadapi Perubahan Iklim: Studi Nelayan Bajo di Kabupaten Sikka, Flores, Nusa Tenggara Timur". Jurnal Masyarakat \& Budaya, 14 (3), hal 599-624.

Putra, A., Husrin, S., Al Tanto, T., dan Pratama, R. 2015. “Kerentanan Pesisir Terhadap Perubahan Iklim Di Timur Laut Provinsi Bali". Majalah Ilmiah Globe, 17(1)hal 43-50.

Badan Pusat Statistik Kota Sabang, Sabang Dalam Angka 2016. BPS Kota Sabang

\section{Website}

Saripurnawan, Djunaidi. 2007. Aceh Pasca Tsunami: Dampak Negatif Bantuan yang Berlebihan. www.kabarindonesia.com. 